\title{
Pengaruh Lingkungan Negatif Terhadap Kedisiplinan Siswa SD Negeri 134 Pekanbaru
}

\author{
Yuliastuti $^{1}$, Rian Vebrianto $^{2}$ \\ Universitas Islam Negeri Sultan Syarif Kasim Riau, Indonesia \\ e-mail: \\ 1yuliastuti@gmail.com. \\ 2rian.vebrianto@uin-suska.ac.id
}

\begin{abstract}
.
This study aims to find out how much negative environmental influences on the implementation of the School Rules of Student's discipline. The aim is to improve the discipline of students - students and carry out school rules well. SD Negeri 134 Pekanbaru. The method used is a Mix Method Research conducted at 134 Public Elementary Schools in Pekanbaru, with sampling techniques by simple random sampling and interviews obtained a sample of 20 students from grades 4.5 and 6 . The disciplinary instruments and student learning discipline are in the form of questionnaires distributed to respondents. The hypothesis proposed is that there is a negative environmental influence on school discipline that is significant to student learning discipline. The dependent variable data analysis and Open variable. Results of descriptive analysis shows that 1) the influence of family environment plays an important role in instilling children's discipline, 2) the influence of the community environment, namely the negative environment around the house becomes an obstacle in the application of discipline in schools, 3) the rules of the school discipline on the discipline of students in SD Negeri 134 Pekanbaru, meaning that if both the influence of the family and community environment, the application of discipline and order in the school will be easy to apply, discipline influences the implementation of school discipline and student discipline.
\end{abstract}

Keywords: Negative environment, discipline

\begin{abstract}
ABSTRAK.
Penelitian ini bertujuan untuk mengatahui seberapa besarnya Pengaruh lingkungan $n$ negatif pada Pelaksanaan Tata Tertib Sekolah terhadap Kedisiplinan belajar Siswa. Tujauannya untuk meningkatkan kedisiplinan siswa - siswa serta melaksanakan tatatertib sekolah dengan baik.SD Negeri 134 Pekanbaru .Metode yang digunakan adalah Mix Methode Penelitian dilaksanakan di Sekolah Dasar Negeri 134 Pekanbaru, dengan teknik pengambilan sampel secara simple random sampling dan wawancara didapat sampel sebanyak 20 orang siswa dari kelas 4,5 dan 6. Instrumen tata tertib dan kedisiplinan belajar siswa berupa lembar pertanyaan (angket) yang disebarkan kepada responden.Hipotesis yang diajukan adalah terdapat pengaruh lingkungan negative terhadap tata tertib sekolah yang signifikan terhadap kedisiplinan belajar siswa.Analisis data variable terikat dan variable terbuka .Hasil analisis penelitian deskritif menunjukan bahwa 1) pengaruh lingkungan keluarga sangat berperan penting dalam menanamkan kedisipilan anak, 2) pengaruh lingkungan masyarakat yaitu lingkungan negatif di sekitar rumah menjadi kendala dalam penerapan kedisiplinan di sekolah, 3) pengaruh pelaksanaan tata tertib sekolah terhadap kedisiplinan siswa di SD Negerin 134 Pekanbaru .artinya jika baik pengaruh lingkungan keluarga dan masyarakat maka penerapan kedisiplinan dan tata tertib yang ada di sekolah akan mudah di terapakan, kediisiplinan berpengaruh kepada pelaksanaan tata tertib sekolahserta terhadap kedisiplinan belajar siswa.
\end{abstract}

Kata kunci: Lingkungan negatif, disiplin, tata tertib 


\section{PENDAHULUAN}

Menurut Undang-Undang Republik Indonesia Nomor 20 Tahun 2003 tentang Sistem pendidikan Nasional Bab 1 Pasal 1 adalah Pendidikan adalah usaha sadar dan terencana untuk mewujudkan suasana belajar dan proses pembelajaran agar peserta didik secara aktif mengembangkan potensi dirinya untuk memiliki kekuatan spiritual keagamaan, pengendalian diri, kepribadian, kecerdasan, akhlak mulia, serta keterampilan yang diperlukan dirinya, masyarakat, bangsa, dan negara.Pernyataan tersebut merupakan salah satu konsep pendidikan yang menekankan betapa penting dan kuatnya peranan pendidikan dalam pembinaan manusia. Artinya pendidikan sebagai suatu kegiatan pembinaan sikap dan mental yang akan menentukan tingkah laku seseorang. Oleh karena itu untuk melestarikan bentuk tingkah laku tersebut seorang pendidik harus mempertahankannya dengan salah satu alat pendidikan yaitu kedisiplinan.

Sekolah merupakan ruang lingkup pendidikan (Wawasan Widyatamandala). Dalam pendidikan ada proses mendidik, mengajar dan melatih. Sekolah sebagai ruang lingkup pendidikan perlu menjamin terselenggaranya proses pendidikan yang baik. Kondisi yang baik bagi proses tersebut adalah kondisi aman, tenang, tertib dan teratur, saling menghargai dan hubungan pergaulan yang baik hal itu dicapai dengan merancang peraturan sekolah, yakni peraturan bagi guru-guru, dan bagi para siswa, serta peraturan-peraturan lain yang dianggap perlu. Untuk sekolah, disiplin itu, sangat perlu dalam proses belajar mengajar. Alasannya yaitu: disiplin dapat membantu kegiatan belajar, dapat menimbulkan rasa senang untuk belajar dan meningkatkan hubungan sosial.

Ketertiban sekolah dituangkan dalam Tata Tertib Peserta Didik, dan disusun secara Operasional untuk mengatur tingkah laku dan sikap hidup peserta didik. Disiplin sekolah apabila dikembangkan dan diterapkan dengan baik, konsisten dan konsekuen akan berdampak positif bagi kehidupan dan perilaku siswa. Disiplin dapat mendorong mereka belajar secara konkret dalam praktik hidup di sekolah tentang hal-hal positif yang melakukan hal- hal yang lurus dan benar dan menjauhi hal-hal yang negatif. Dengan pembarlakuan disiplin, siswa belajar beradaptasi dengan lingkungan yang baik itu, sehingga muncul keseimbangan diri dalam hubungan dengan orang lain

Dalam penelitian ini terdapat dua variabel yang akan diteliti yaitu pelaksanaan tata tertib dan kedisiplinan sebagai variabel terbuka sedangkan lingkungan keluarga dan lingkungan masyarakat merupakan variable terikat Berkenaan dengan ke dua variabel tersebut yaitu tata tertib sekolah dan yang mendasari penelitian ini bersumber pada teori (Mulyono, 2000:14) Tata tertib adalah kumpulan aturan-aturan yang dibuat secara tertulis dan mengikat anggota masyarakat. (Depdikbud, 2001:37) Tata tertib sekolah adalah aturan atau peraturan yang baik dan merupakan hasil pelaksanaan yang konsisten dari peraturan yang ada. Secara umum tata tertib sekolah dapat diartikan sebagai ikatan atau aturan yang harus dipatuhi oleh setiap warga sekolah tempat berlangsungnya proses belajar mengajar. Pelaksanaan tata tertib sekolah akan dapat berjalan dengan baik jika guru, aparat sekolah dan siswa telah saling mendukung terhadap tata tertib sekolah itu sendiri. Kurangnya dukungan dari siswa akan mengakibatkan kurang berartinya tata tertib sekolah yang diterapkan di sekolah.

\section{KAJIAN LITERATUR}

Tata tertib sekolah menurut Nawawi (2001:161) mencakup aspek-aspek (1) tugas dan kewajiban dalam kegiatan intra kurikuler dan kegiatan ekstra, (2) Larangan-Iarangan bagi para siswa, (3) sanksi-sanksi bagi para siswa. 
Tata tertib sekolah bukan hanya sekedar kelengkapan dari sekolah, tetapi merupakan kebutuhan yang harus mendapat perhatian dari semua pihak yang terkait, terutama dari pelajar atau siswa itu sendiri.Sehubungan dengan hal tersebut, maka sekolah pada umumnya menyusun pedoman tata tertib sekolah bagi semua pihak yang terkait bagi guru, tenaga administrasi maupun siswa.Isi tata tertib sekolah secara garis besar adalah berupa tugas dan kewajiban siswa yang harus dilakukan, larangan dan sanksi.

Pada hakikatnya tata tertib sekolah baik yang berlaku umum maupun khusus meliputi tiga unsur (Suharsimi, 2001:123-124) yaitu (1) Perbuatan atau tingkah laku yang diharuskan dan dilarang, (2) Akibat atau sanksi yang menjadi tanggung jawab pelaku atau pelanggar peraturan, (3) Cara atau prosedur untuk menyampaikan peraturan atau subjek yang dikenai tata tertib sekolah tersebut.

Menurut Sanjaya (2006:272-273) ada empat faktor yang merupakan dasar kepatuhan seseorang terhadap nilai tersebut, yaitu (1) Normativist, biasanya kepatuhan pada normanorma hokum yang terdapat dalam tiga bentuk, yaitu kepatuhan terhadap nilai atau norma itu sendiri, kepatuhan pada proses tanpa memperdulikan normanya sendiri., kepatuhan pada hasilnya/tujuan yang diharapkan dari peraturan itu, (2) Integralis, yaitu kepatuhan didasarkan pada kesadaran. dengan pertimbangan pertimbangan yang rasional, (3) Fenomenalist, yaitu kepatuhan berdasarkan suara hati/sekedar basa-basi, (4) Hedonist, yaitu kepatuhan berdasarkan kepentingan sendiri.

Dari keempat faktor tersebut yang menjadi dasar kepatuhan setiap individu tertentu saja yang kita harapkan adalah kepatuhan yang bersifat normativist, sebab kepatuhan yang semacam ini adalah kepatuhan didasari kesadaran akan nilai, tanpa memperdulikan apakah tingkah laku itu menguntungkan bagi dirinya atau tidak.

Fungsi dan tujuan dari tingkat disiplin belajar siswa adalah untuk meningkatkan kualitas pengetahuan pengetahuan yang telah dilakukan oleh para siswa. Adapun menurut Rachman (2004: 35-36), pentingnya disiplin bagi para siswa adalah untuk (1) Memberikan dukungan bagi terciptanya perilaku yang tidak menyimpang, (2) Membantu siswa memahami dan menyesuaikan diri dengan tuntutan lingkungan, (3) Cara menyelesaikan tuntutan yang ingin ditunjukan peserta didiknya terhadap lingkungan, (4) Untuk mengatur keseimbangan keinginan individu satu dengan individu lainnya, (5) Menjauhi siswa melakukan hal-hal yang dilarang disekolah, (6) Mendorong siswa melakukanhalhal yang baik dan benar, (7) Peserta didik belajar dan bermanfaat baginya dan lingkungannya, (7) Kebiasaan baik itu menyebabkan ketenangan jiwanya dan lingkungan.

\section{Faktor-Faktor yang Mempengruhi Tata Tertib Sekolah}

Adapun faktor-faktor yang mempengaruhi Tata Tertib Sekolah menurut Mulyono, (2000:60-64) adalah Faktor lingkungan keluarga, factor lingkungan sekolah dan factor lingkungan masyarakat.

Faktor lingkungan rumah atau keluarga ini merupakan lingkungan pertama dan utama dalam menentukan perkembangan pendidikan seseorang, dan tentu saja merupakan factor pertama dan utama pula dalam menentukan belajar seseorang. Orang tua adalah penanggung jawab keluarga. Dalam pendidikan keluraga menjadi suatu kebutuhan yang mendasar, sebab keluarga adalah awal dimana anak mengenal dengan orang lain dan dirinya sendiri, serta pertama-tama mendapatkan pendidikan, yaitu pendidikan yang diberikan oleh kedua orang tuanya dan merpakan kewajiban yang diberikan oleh kedua orang tuanya dan merupakan kewajiban yang bersifat agamis. Selain pendidikan dalam keluarga, pendidikan di sekolah diperoleh seseorang secara teratur, sistematis, bertingkat mulai dari TK hingga perguruan tinggi. 
Faktor lingkungan masyarakat juga mempengaruhi siswa. Kegiatan siswa dalam masyarakat dapat menguntungkan terhadap perkembangan pribadinya. Tetapi kalau kegiatan siswa terlalu banyak maka akan terganggu belajarnya, karena ia tidak bisa mengatur waktu. Dalam Masyarakat juga terdapat teman bergaul. Pengaruh ini siswa lebih cepat masuk dalam jiwanya dari pada yang kita duga. Teman yang baik membawa kebaikan, seperti membawa belajar bersama, dan teman pergaulan yang kurang baik adalah yang suka begadang, pecandu rokok, dan sebagainnya maka berpengaruh sifat buruk juga. Bentuk kehidupan masyarakat, yakni apabila kehidupan masyarakat yang terdiri dari orang-orang yang berpendidikan, terutama anak-anaknya rata-rata bersekolah tinggi dan moralnya baik. Masyarakat yang terdiri dari orang-orang tidak terpelajar, penjudi, suka mencuri dan mempunyai kebiasaan yang tidak baik, akan berpengaruh jelek kepada anak yang berada dilingkungan itu.

Berdasarkan uraian-uraian diatas maka dapat disimpulkan faktor-faktor yang mempengaruhi tata tertib sekolah antara lain: lingkungan keluarga, lingkungan sekolah dan lingkungan masyarakat.

\section{METODE PENELITIAN}

\section{Metode Campuran (Mixed Methods)}

Rancangan penelitian metode campuran (mixed methods research design) adalah suatu prosedur untuk mengumpulkan, menganalisis, "dan mencampur" metode kuantitatif dan kualitatif dalam suatu penelitian atau serangkaian penelitian untuk memahami permasalahan penelitian (Cresswell\&Plano Clark, 2011).

Asumsi dasarnya adalah penggunaan metode kuantitatif dan kualitatif secara gabungan. Berdasarkan asumsi tersebut, memberikan pemahaman yang lebih baik tentang permasalahan dan pertanyaan penelitian daripada jika secara sendiri - sendiri.

Pada pelaksanaannya dibutuhkan ketrampilan tertentu dalam penggunaan metode ini, yaitu : (1) prosedurnya memakan banyak waktu, (2) membutuhkan pengumpulan, (3) analisis data ekstensif.

\section{Pengolahan data dengan mixed methods}

Langkah pengolahan data dengan mixed method adalah melibatkan merging (menyatukan/ menggabungkan), Connecting (menghubungkan/membuat basis data yang satu menjelaskan basis data yang lain), Building (membangun/membuat basis data yang satu membangun sesuatu yang baru yang digunakan dalam basis data yang lain), Embedding (menanamkan/menempatkan basis data yang satu dalam basis data lain yang lebih besar), Di -mixed (dicampur) dalam penelitian metode campuran.

\section{Rancangan Metode}

Rancangan metode menggunakan rancangan konvergen. Rancangan konvergen adalah mengumpulkan data kuantitatif dan kualitatif secara simultan, menggabungkan datanya, membandingkan hasilnya, dan menjelaskan semua deskripsi dalam hasilnya.

Tujuan dari rancangan ini, adalah untuk menjelaskan hasil kuantitatif dengan data kualitatif dari suatu penelitian untuk melihat apakah mereka berkonvergensi dan memberikan hasil serupa.

\section{HASIL DAN PEMBAHASAN}

Dalam Penelitian ini melibatkan seramai 20 orang siswa kelas 4,5,dan 6 SD Negeri 134 Pekanbaru Dan wawancara dengan orang tua terdiri dari 3 keluarga, 4 siswa 2 orang siswa laki-laki dan 2 orang siswa perempuan dalam pelaksanaannya. Data dari hasil analisis secara deskriptif dapat mengambarkan bagaimana profil peserta penelitian yaitu siswa kelas 
4,5,dan 6 SD Negeri 134 Pekanbau dan 3 kepala keluarga . Adapun uraian secara terperinci seperti pada tabel 7.1 matrik variable dan indicator.

\begin{tabular}{|c|c|c|c|}
\hline Variabel & dimensi & Indikator & Reponden \\
\hline \multirow[t]{2}{*}{ Perhatian dan motivasi } & - Keluarga & - Lingkungan keluarga & - Orang tua \\
\hline & - Masyarakat & $\begin{array}{l}\text { - Perbuatan negative di } \\
\text { Lingkungan masyarakat }\end{array}$ & - siswa \\
\hline Membiasakan disiplin & $\begin{array}{l}\text { Keluarga } \\
\text { Sekolah }\end{array}$ & $\begin{array}{l}\text {-Terlambat bangun } \\
\text {-terlambat datang ke } \\
\text { sekolah }\end{array}$ & $\begin{array}{l}\text { Orang tua } \\
\text { siswa }\end{array}$ \\
\hline Tata tertib & Sekolah & $\begin{array}{l}\text { Membuang sampah pada } \\
\text { tempatnya }\end{array}$ & Siswa \\
\hline
\end{tabular}

Tabel.7.1 menujukan perhatian dan motivasi orang tua sebagai variabel terikat dimensi keluarga dan masyarakat, indicator lingkungan keluarga, lingkungan masyarakat dengan responden orang tua dan siswa. Membiasakan disiplin dan mematuhi tata tertib di sekolah merupakan variebel bebas demensi keluaraga dan sekolah, indikator terlambat bangun dan terlambat datang ke sekolah dengan responden orang tua dan siswa. yang tinggal di Kampung Dalam 100\%, aspek pendidikan ayah SD 50\%, SMP 20\%, SMA 30\%, aspek pendidkan ibu SD 55\%, SMP 25\%, dan SMA $20 \%$. Sedangkan aspek pekerjaan ayah buruh $25 \%$, karyawan $15 \%$, jualan $45 \%$ dan wiraswasta $15 \%$, pekerjaan ibu buruh $20 \%$, karyawan 10\%,jualan 10\% dan ibu rumah tangga sebasar $60 \%$

\section{Analisis Deskriptif}

Sebelum analisis ini dijalankan, untuk diketahui bahwa instrumen angket ini memiliki realibilitas yang tinggi yaitu dengan pengisian skala A pada pilihan jawaban jika diatas nilai tersebut maka instrumen ini sangat baik dan efektif

Tabel 7.2 Hasil realibilitas Angket

\begin{tabular}{|l|l|l|l|l|}
\hline No & Peryataan & No intem & Pilih Jawaban & Kualitas \\
\hline 1 & $\begin{array}{l}\text { Saya tidur diatas pukul } \\
\text { 21.00 WIB. }\end{array}$ & 5 & $\begin{array}{l}\text { SL-S } \\
\text { KD-JR } \\
\text { TP }\end{array}$ & $\begin{array}{l}6 \\
\text { TP }\end{array}$ \\
\hline 2 & $\begin{array}{l}\text { Saya melihat perbuatan } \\
\text { yang negative di sekitar } \\
\text { rumah }\end{array}$ & 9 & SL-S \\
\hline 3 & $\begin{array}{l}\text { Saya terlambat datang ke } \\
\text { Kekolah }\end{array}$ & 1 & 12 \\
& TP & 3 \\
\hline 4 & $\begin{array}{l}\text { Saya mematuhi tata tertib } \\
\text { sekolah }\end{array}$ & SL-S & 5 \\
\hline & KD-JR & 4 \\
TP & 8 \\
\hline
\end{tabular}

\begin{tabular}{|l|c|l|l|}
\hline Aspek & Nilai & N & Persentase \\
\hline Umur siswa & 9 & 3 & $15 \%$ \\
& 10 & 5 & $30 \%$ \\
& 11 & 4 & $20 \%$ \\
\hline
\end{tabular}




\begin{tabular}{|c|c|c|c|}
\hline & $\begin{array}{l}12 \\
13 \\
14\end{array}$ & $\begin{array}{l}3 \\
3 \\
1\end{array}$ & $\begin{array}{l}15 \% \\
15 \% \\
5 \%\end{array}$ \\
\hline Alamat & $\begin{array}{l}\text { 1. Kampung } \\
\text { Dalam } \\
\text { 2. Lain-lain }\end{array}$ & 20 & $100 \%$ \\
\hline $\begin{array}{l}\text { Pendidikan } \\
\text { ayah }\end{array}$ & $\begin{array}{ll}\text { 1. } & \text { SD } \\
\text { 2. } & \text { SMP } \\
\text { 3. } & \text { SMA }\end{array}$ & $\begin{array}{l}10 \\
4 \\
6\end{array}$ & $\begin{array}{l}50 \% \\
20 \% \\
30 \%\end{array}$ \\
\hline $\begin{array}{l}\text { Pendidikan } \\
\text { ibu }\end{array}$ & $\begin{array}{ll}\text { 1. } & \text { SD } \\
\text { 2. } & \text { SMP } \\
\text { 3. } & \text { SMA } \\
\end{array}$ & $\begin{array}{l}11 \\
5 \\
4\end{array}$ & $\begin{array}{l}55 \% \\
25 \% \\
20 \%\end{array}$ \\
\hline $\begin{array}{l}\text { Pekerjaan } \\
\text { ayah }\end{array}$ & $\begin{array}{l}\text { 1. Buruh } \\
\text { 2. Karyawan } \\
\text { 3. Jualan } \\
\text { 4. Wiraswasta }\end{array}$ & $\begin{array}{l}5 \\
3 \\
9 \\
3 \\
\end{array}$ & $\begin{array}{l}25 \% \\
15 \% \\
45 \% \\
15 \% \\
\end{array}$ \\
\hline $\begin{array}{l}\text { Pekerjaan } \\
\text { Ibu }\end{array}$ & $\begin{array}{l}\text { 1. Buruh } \\
\text { 2. Karyawan } \\
\text { 3. Jualan } \\
\text { 4. Ibu Rumah } \\
\text { Tangga }\end{array}$ & $\begin{array}{l}4 \\
2 \\
2 \\
12\end{array}$ & $\begin{array}{l}20 \% \\
10 \% \\
10 \% \\
60 \%\end{array}$ \\
\hline
\end{tabular}

Dari tabel 7.2 diatas diketahui bahawa semua variabel yang menjadi variabel penentu pengaruh lingkungan negatif terhadap kedisisplinan siswa SD Negeri 134 Pekanbaru, dimana kurangnya perhatian orang tua terhadap prilaku anaknya di sekitar rumah dan melihat prilaku negatif di sekitarnya tidak di awasi sehingga anak menghabiskan waktunya rumah salah satu penyebab anak tidur terlalu malam. Hal ini sangat penting untuk memastikan data yang masuk dan dianalisis adalah data dengan menggunakan instrumen yang tepat dan bermakna.

\section{Analisis Wawancara}

Untuk menguatkan hasil dan pembahasan analisis secara kuantitatif dijalankan juga analisis secara kualitatif dengan hasil analisis wawancara dengan 3 kepala keluarga ayah dan ibu serta 4 orang anak, 2 orang laku-laki dan 2 orang perempuan. Secara umum pengaruh negatif di lingkungan rumah atau masyarakat dapat mempengaruhi kedisipilanan siswa - siswa SD Negeri 134 pekanbaru tidak adanya motivasi dan perhatian dari orang tua kepada anaknya agar membiasakan hidup teratur, pengaruh lingkungan negatif di sekitar rumah menyebabkan orang tua kesulitan dalam menerapkan disiplin dalam keluarga , factor kesibukan bekerja karena baik ayah dan ibu sebagian bekerja sebagai buruh.faktor sarana dan prasarana sekolah serta perhatian dan peran kepala sekolah sebagai pimpinan di sekolah beserta para guru untuk selalu mendidik dan membiasakan hidup tertib dan disiplin.

\section{KESIMPULAN}

Dari data kuesioner dan wawancara siswa kelas 4,5,dan6 SD Negeri 134 Pekanbaru pengaruh lingkungan keluarga dan lingkungan masyarakat di sekitar tempat tinggalnya berperan dalam membentuk karakter disiplin kepada anak .dan sekolah sebagai pendidikan formal senantiasa menanamkan kedisiplinan dengan berbagai pendekatan yang tidak menimbulkan keterpaksaan namun dengan kesadaran diri sepenuhnya. 


\section{DAFTAR PUSTAKA}

Ihsan, Fuad.1997. Dasar-Dasar Kependidikan. Jakarta: PT Rineka Cipta

Ahmadi, Abu. 1991. Sosiologi Pendidikan. Jakarta: PT Rineka Cipta

Tu'u, Tulus. 2004. Peran Disiplin Pada Perilaku dan Prestasi Siswa. Jakarta: Grasindo Yusuf, Muri. 1986. Pengantar Ilmu Pendidikan. Jakarta: Ghalia Indonesia.

Sanjaya 2006, empat faktor yang merupakan dasar kepatuhan seseorang

Barnett, E., \& Casper, M. (2001). A definition of social environment. American Journal of Public Health. Diakses pada tanggal

Gonzales, N. A. et al. (1996). Family, peer, and neighborhood influences on academic achievement among African-American adolescents: one year prospective effects. American Journal of Community Psychology, Jun 1996; 24, 3;Proquest (versi elektronik). 10 Oktober 2013 dari http://www.ncbi.nlm.nih.gov/pmc/article s/PMC1446600/pdf/11249033.pdf.

Berns, R. M. (2010). Child, family, school, community. Wadsworth: Cengage Learning.

Bowen, G.L et al. (2008). Changes in the social environment and the school succes of middle school: $A$ longitudinal Analysis. Diambil pada tanggal 28 Juni 2013dari www.proquest.com.

Hadiyanti, Yosefin Rianita. (2012). Pengaruh pola asub orangtua, motivasi belajar, dan sikap siswa pada pelajaran matematika terhadap prestasi belajar matematika siswa SMP. Tesis Magister, tidak diterbitkan, Universitas Negeri Yogyakarta, Yogyakarta. 
